\title{
Determinants of Sales Force Performance in Banking Sector: A Case of Malaysia
}

\author{
Zunarni Kosim*, Nor Hayati Ahmad, Tan Sek Choo \\ College of Business, Universiti Utara Malaysia, Malaysia \\ *zunarni@uum.edu.my, profyati@gmail.com,tan@uum.edu.my
}

\begin{abstract}
Globalisation, deregulation, technology, competition and new customers' needs influence the banks to adopt marketing approach in promoting their product and services to generate income. In this aspect, personal selling which focuses on selling skills of banking employees becomes a very important banking function. This study intends to investigate the relationship between the determinants namely teamwork, learning, leadership, communication and, high performance culture and Key Performance Indicators (KPI). Inspite of the importance of KPI in measuring performance of salesforce, there is a lack of published empirical findings to explain the influence of these predictors on KPI achievement in banking sector.This study reported that the model explains 0.21 percent of the variance in KPI achievement. In which teamwork and high performance culture are found to be positive and significantly related. This new finding appears to imply that bank should cultivate and promote teamwork and high performance culture to ensure KPI highly achievable and enhance banks profitability.
\end{abstract}

Keywords: Salesforce, banking, KPI, high performance culture, teamwork

\section{Introduction}

Globalisation, deregulation, technology, competition and new customers' needs influence the banks to adopt marketing approach in promoting their product and services to generate income. In this aspect, personal selling which focuses on selling skills of banking employees becomes a very important banking function. With the advancement of technology, rapid development in innovative products in financial services industry banks become more competitive in terms of achieving and sustaining high profit performance. As a strategy banks employ staff to be involved in sales of banking products and services. Sales in banking cover two types of financial products and services; i) interest -based ii) fee-based products. Interest-based products comprise of mortgage loan, Bumiputra Unit Trust loan (ASB) and personal loan while fee-based products covers investment products, bancasurance (health insurance, education insurance etc) and credit card. In term of customer-type, the sales force has to target two major types of market segments namely corporate customers and retail customers. In term of scope, sales involve direct sales and cross selling. Direct sales are those sales involving pre-determined products such as mortgage loans, ASB loan while in cross selling, the sale force has to sell products which are complimentary to the pre-determined products and other products determined by the bank's management. For example in selling mortgage loan, the sales force will also sell MRTA (Mortgage Reducing Term Assurance) and other products; internet banking services.

Nowadays, banking industry is highly affected by intense competition. However, the existing performance measurement is traditional in nature and become less competitive in the new banking environment. Presently, manay banks are using the modern approach of performance measurement called as Key Performance Indicator (KPI). KPI has gained increasing popularity and attention among the industry players but not among the researchers. Hence, this paper provide the empirical evidents on performance measurement in banking sectors using KPI. The merits of KPI is that it measures both financial and nonfinancial results and it is also robust in nature because it consists of four performance elements namely financial, customer, process and learning growth. The performance observation under financial are on achievement of sales target, acquiring new and retaining customers, while for customers; improvement in turnaround time and service index. The performance observation under process is the ability of sales force to maintain or improve from previous years' audit rating. Learning growth elements on the other hand is measured by the numbers of times the salesforce attending courses and training for period under review. Therefore, the existing performance measurement in banking sector needs a new performance measurement such as KPI in order to achieve both operational and financial goals. 
KPI originated from the balance score card (BCC) used by organization as performance measurement system to measure both organizational and staff performance (Karr, 2005; Kuvaas, 2007). Based on the balance score card Wua, Tzeng \& Chen (2009) improved the system to produce KPI as a new system of performance measurement in bank. Callahan (2003) discovered several benefits of the new performance measurement. First, KPI links employees' current performance with his/her previous performance or against his/her banks' target. This analysis will reveal the degree of changes between actual achievement and target as well as the improvement required in the future. Second, KPI is target set by bank with a date for accomplishment. The accumulation of individual sales target forms the overall banks' (Callahan, 2003). Third, it is very vigorous as it measures both financial and non-financial results achieved by the sales force. Forth, KPI also builds flexibility into the performance measurement system and reaps an acceptance by all levels of management (Crandall, 2002). Since some banks are still using balance score card (BSC), while others employ the new method using KPI; the performance measurement in banking industry becomes more complex and challenging. Todate, hardly any empirical academic research has been published involving salesforce performance measurement using KPI. The only published finding is by Zakaria et al. (2011) but this study involved KPI achievement government servants in Malaysia.Due to lack of empirical research it is the objective of this paper to investigate and to present the findings on the determinants of salesforce performance based on KPI application.

Problem statement: One of the main problem faced by Malaysian banks is the difficulties to identify factors that enhance salesforce's performance. This is important because salesforce's performance contributes significantly banking group perforamance. Nowithstanding that little reserach has been undertaken specifically to identify the factors which could enhance salesforce's performance. The gap in this area has resulted in no systematic identification of factors both at individual and organizational levels. A survey report by CSO in 2011 revealed that, only 53.3\% of the sales force achieved or exceeded their targets. The finding suggest that banks need to identify the types of characteristics of the performing salesforce. Therefore, further investigation need to be undertaken to address the problem of handling the $46.7 \%$ of the sales force that have not met or exceeded their targets. Many practices today use psychometric test to screen potential sales perfomers. With many factors existing in psychometric test, bank management often to get confused as to which factors should be given priority while selecting candidates for sales force position. There is no matrix containing salient factors would could help bank management in their selection decision. The unavailability of such matrix constraints wider application of psychometric test in the banking industry.

\section{Literature Review}

Verbeke, Dietz \& Verwaal (2011) conducted a study entitled: Drivers of Sales performance: A contemporary meta analysis: Have salespeople becomes knowledge workers. The study produces evidenced that the following factors are among the drivers of salesforce performance: communication, learning, leadership, culture and teamwork. The following are related literature review on variables.

Communication: Scudder \& Guinan (1987) conceptualized communication competence by using three dimensions which are encoding, decoding and maintaining user relation. Encoding and decoding is referring to the ability of individual to understand another person and to communicate the idea to other persons effectively selling (Govaerts et al., 2011). Both dimensions are the traditional way to measure communication competency. While, maintaining user relation means that the ability of individual to communicate in relation to the specific task. Communication competence is essential in personal selling as it permits an interaction between sales force and customer which in turn leads to success in selling (Govaerts et al., 2010). Along with this line of thought, Mantrala, Sridhar, \& Dong (2012) found there are no significant differences in term of communication skills requirements for three types of sales jobs namely balanced firm, customer acquisition and customer retention. Good communication skills like persuasion, written, oral and nonverbal skills are expected from sales recruiters in all positions. It has been proven as communication skills recorded a very high importance ratings by the vast majority of respondents in past surveys of salesperson success factors which has been done in the developed world. 
Downing (2011) found changes in pitch and volume, used language that customer can understand, used short and affirmative word, and listen to customers are elements classifed as communication competence among the call centre agents in Western United States. Goebel, Deeter-Schmelz, \& Kennedy (2013) also found listening skill was important to sales job and it was reported significant with salesperson self- efficacy. The researchers also reported self-efficacy is positively influenced customer relationship development, representative job performance, and satisfaction with the manager. This finding strengthens Fohlke (2006) who found communication competence (presentation skill) is positively correlated with sales performance. It is also supported Johlke \& Duhan (2001) who found communication quality is strongly associated with salesperson communication satisfaction. In turn, communication satisfaction is positively associated with job satisfaction and organizational commitment.

Learning: Bell, Mengüç, \& Widing (2010) defined learning as the sales force's ability to create knowledge through the transformation of experiences and through testing the concepts. While, Kohli et al. (1998) define learning as a sales force's self- improvement in term of skills, knowledge and abilities that lead to a better performance. Hence, sales force with learning orientation has a strong desire to improve and master their selling skills and abilities continually. Bell et al. (2010) reported that learning ability was significant with store performance among the retail salesforce. This finding supports Kohli et al. (1998). The researchers posit that learning is very important as it is a source of a company's competitive advantage.

Leadership: According to MacKenzi \& Podsakoff (2001), transformational and transactional leadership behaviour have been widely research. Transformational leadership behaviour is a leadership style which emphasises on articulate the vision, provide appropriate role model, foster the accpetance of goal, provide individualized support and intelectual stimulation and express high performance expectation. While, transactional leadership behaviour is more related to leadership style that emphasises on reward and punishment or feedback. Recently many literatures discuss on servant leadership which is a new paradigm of leadership behaviour. According to Jaramillo, Grisaffe, Chonko, \& Roberts, (2009), the leader who posses servant leadership will consider the needs of the followers as his priority. Chen \& Silverthorne (2005) argued that leadership behaviour help employees to increase their job performance and job satisfaction. On the other hand, it can reduce job stress and turnover intention among the employees. This finding is consistent with Yukl (2012) who contended leadership style in an organization is able to influence and facilitate individual employees and collective efforts to accomplish shared goals or improve performance.

Shannahan, Bush, \& Shannahan (2013) found that sales performance will be higher under influenced of transformational leadership among the salesforce in food an beverages companies in United States. This finding supported Verbeke et al., (2011) empirically reported that supervisory leadership particularly the transformational leadership has positive, significant impact on self report performance. Panagopoulus \& Dimitriadis (2009) on the other hand provided an evidence for the mediating effect of transformational leadership on behaviour based control and sales person key outcomes. The researchers also found transformational leadership has positive relation with affective commitment and satisfaction with supervisory. For this study, leadership style that focus on articulate visionary will predict sales performance and the retention among salesforce. Articulate visionary leadership style has been defined as leader's/manager's behaviour that is aimed at the identification and expression of a clear vision in future (MacKenzi \& Podsakoff, 2001).

High performance culture: Organizational culture has been defined as pattern of values, beleifs and expectation shared by members of organization which produce norms to shape and controls the behaviour members (Williams \& Attaway, 1996). High performance culture on the other hand has been defined as a demonstration of both high levels of engagement (passion, commitment and drive for results) among the employees and a strong alignment of people practices with organization strategy and brand (Nesbit, 2005). While, Robson (2005) found that employees who embraced high performance culture will do their daily operational activities and also to continually assist in improving the organization performance.Doç, Akdem, \& Erdem (2010) on the other hand reported that high performance culture provides employees with the accountability and responsibility necessary to meet customers' needs in a timely manner in order to ensure business success. Mualla (2011) described the employees of high performance culture as "engaged" with organization. 
Hence, the difference between ordinary organizational culture and high performance culture is the level of employees "engagement". Harrim (2010) put forward that engaged employees will work significantly as compared to others. As a result they more likely to stay with the company and better at generating customer loyalty (Mualla, 2011).

Teamwork: Griffin, Patterson, Malcolm, \& West (2001) assert that teamwork requires employees to work cooperatively to achieve a group's goals. El-Ansary, Zabriskie, \& Browning (1993) defined teamwork as the deliberate actions taken by management to ensure that the support needed by sales force will come from both the internal company units and the managers. Spencer \& Spencer (1993), teamwork implies a genuine intention to work cooperatively among the employees in organizations and it eliminates the elements of competition. In addition, Harrim (2010) affirmed that teamwork reflects organization's vital quality. Therefore the implementation of teamwork can accomplish the sales objective and assure customers' satisfaction in sales organization(El-Ansary, Zabriskie, \& Browning, 1993), foster commitment and team spirit with others for achieving goals (Rodriguez, Patel, Bright, Gregory, \& Gowing ,2002) and motivate to work and increase job satisfaction. Piercy, W.Cravens, Nikala, \& Vorhies (2006) reported team building has direct impact on salespersons' outcome performance. This finding is consistent with El-Ansary et al. (1993). The in-role performance is found partially mediated the relationship between teamwork and salesperson outcome performance in Piercy, W.Cravens, Nikala, \& Vorhies (2006). Teamwork however has a mixed result with job satisfaction. It was found significant but with inverse relationship with job satisfaction (Griffin et al., 2001) and not significant at all with job satisfaction (Loveland, Lounsbury, Park, \& Jackson, 2015). Albrecht (2013) showed team climate was positively associated with engagement and job resources in multi-national company.

Table 1: Key Performance Indicators for Banking

\begin{tabular}{|c|c|c|}
\hline $\begin{array}{l}\text { Key Result Areas } \\
\text { (KRAs) }\end{array}$ & $\begin{array}{l}\text { Key Performance Indicators } \\
\text { (Titko \& Lace, 2010) }\end{array}$ & $\begin{array}{l}\text { Key Performance Indicators } \\
\text { (Wu et .al, 2009) }\end{array}$ \\
\hline Financial & $\begin{array}{l}\text { ROA, ROE } \\
\text { Cost/Income Ratio } \\
\text { Revenue For New Products } \\
\text { Revenue per Salesperson } \\
\text { Market Share for Asset } \\
\text { Market Share for Deposit }\end{array}$ & $\begin{array}{l}\text { Operating Revenue } \\
\text { revenue) } \\
\text { Debt Ratio } \\
\text { Return on Asset (ROA) } \\
\text { Earnings Per Share (EPS) } \\
\text { Profit Margin } \\
\text { Return on Investment (ROI) }\end{array}$ \\
\hline Customer & $\begin{array}{l}\text { Customer satisfaction and loyalty } \\
\text { index } \\
\text { Revenue and cost for customers } \\
\text { Customer Retention Rate } \\
\text { New Customer Acquisition Rate } \\
\text { New Customers per Employees } \\
\text { Number of customers complaint }\end{array}$ & $\begin{array}{l}\text { Customer Satisfaction } \\
\text { Profit per Online Customer } \\
\text { Market Share } \\
\text { Customer Retention } \\
\text { Customer Increasing Rate } \\
\text { Profit per Customer }\end{array}$ \\
\hline Internal process & $\begin{array}{l}\text { Request Fulfilment Time } \\
\text { Transaction per Employees } \\
\text { Number of Errors according to Audit } \\
\text { Result } \\
\text { Customers Complaint }\end{array}$ & $\begin{array}{l}\text { Number of New Service Items } \\
\text { Transaction Efficiency } \\
\text { Customer Complaints } \\
\text { Rationalization Forms and Process } \\
\text { Sales Performance } \\
\text { Management Performance }\end{array}$ \\
\hline Learning and Growth & $\begin{array}{l}\text { New Revenue for Salesperson } \\
\text { Sales Contact per Salesperson } \\
\text { Number of Sold Product by } \\
\text { Salesperson } \\
\text { Number of Errors per Employees } \\
\text { Qualification Test Results }\end{array}$ & $\begin{array}{l}\text { Response of Customers Service } \\
\text { Professional Training } \\
\text { Employees Stability } \\
\text { Employees Satisfaction } \\
\text { Organization Competence }\end{array}$ \\
\hline
\end{tabular}

Source: Titko \& Lace (2010) and Wu (2012) adopted from Wu et al. (2009) 
Key Performance Indicator (KPIs): The traditional salesforce performance measurement tool has been criticized in literature. Crandall (2002) pointed out that conventional performance measure which is stresssing more on financial performance but less on quality and customer service as incompatible. He suggested the existing performance measurement needs an improvement particularly in achieving both operational and financial goals. Grasing (2003) highlighted that the performance measurement in banking industry is more challenging. This is because banking industry is exposed to rapid changes in technology, delivery channels, and sales strategy, segmentation and management practices. Hence, banks continually need to respond to the changes either by changing objectives, shifting resources or varying its operational tools. Karr (2005) found that many organizations use key performance indicators (KPIs) to measure both organizational and staff performance. Harim, (2010) provides evidence on the utilisation of KPIs at organizational level in pharmaceutical industry. This study was extended to banking industry by Wu (2012) and he found the most essential KPIs elements for banking performance are customer satisfaction, sales performance and customer retention rate. As far as Malaysian banking industry, Maybank Annual Report (2015, pp.38) has disclosed an evidence on the utilisation of KPI in Maybank. Other successful financial service companies which are adopters of KPIs are Unibanco (Brazil), DnB Nord Bank (Scandinavian and Baltic region), Nordea Bank (North Europe and Baltic region), Chemical Bank (USA), KeyCorp (USA), Bank of TokyoMitsubishi (Japan), Wells Fargo Bank (USA), Lloyds TSB Bank (UK) and others (Titko \& Lace, 2010). Table 1 presents Wu (2012) on selected KPI for retail banking.

\section{Methodology}

Sample: In this study eight commercial banks were selected and the data required comprising branches distribution by states as at December 2013 and the number of sales forces per branch were taken as at December 2013. This study used survey method where respondents were personally approached by researcher or researcher representative by giving them a copy of the questionnaire. The sample was selected from three regions of Malaysia (Northern, Central and Southern. The sampling procedure used for this study was stratified random sampling (SRS). First, stratification was done on the banks where banks' branches were proportionately determined. Next, stratification on branches was done by region. Based on this stratification the number of respondents (sales force) was total 4242 (1414 branches x 3 sales force.). This estimation method is based Jantan \& Honeycutt (2013). To ensure the minimal response number obtained and taking into account that survey method has high probability of poor response rate, the researcher summed that 600 questionnaires must be distributed to the identified sales force (Nik Kamariah, 1995). Banking sales forces who participate were given three weeks to complete the survey. The survey package consists of a cover letter and one printed copy of questionnaire in English. Two weeks after the questionnaires have been distributed, the researcher reminded the respondents to complete the survey. On the third week, the researcher collected the completed survey from the participating sales forces for analysis.

Survey Measurement: The researcher used two types of scale in the questionnaire. In the first part of the questionnaires, the researcher used the 5-Likert scale. While, the second part of questionnaire consisted of 13 respondents' demographic related items and organizational information. Learning competency was measured using adapted instrument used by Kohli et al. (1998). It involves six items on a five -point Likerttype scale ranging from " $1=$ strongly disagree" to " $5=$ strongly agree". The reliability measured in their study was 0.79 . The instrument for communication chosen for this study was adapted from the Scudder and Guinan (1987). These three dimensions inclusive of seventeen items scale used to measure the effective communication competency. This study employs five-point likert type-scale ranging from $5=$ very important, 4 = important, 3 = not sure, 2 = less important and, 1 = not important. Salesforce perception on an articulate visionary leadership was measured using five items measurement adapted from Schwepker and Good (2010). This study employs five-point likert type-scale ranging from $5=$ strongly agree, $4=$ agree, $3=$ not sure, $2=$ disagree and, 1 = strongly disagree. 
The sales force perception on high performance culture in bank was assessed using an eleven-item scale. Six items were adapted from Nesbit (2005), while the other five items were adapted from Harrim (2010). Respondents viewed high job quality in banking on a five point-likert scale-type, ranging from $5=$ always, $4=$ often, $3=$ not sure, $2=$ seldom, and $1=$ never. Salesforce perception toward sales teamwork has been developed based on work done by Mualla (2011) and Spencer and Spencer (1993). The questions regarding this sales teamwork were measure using five items scale. However, for the purpose of presence study, the wording of four item scales drawn from Mualla (2011) was modified slightly to match the domain of local bank sales force. This study employs a five point-likert scale-type, ranging from $5=$ strongly agree, $4=$ agree, 3 $=$ not sure, 2 = disagree, and $1=$ strongly disagree. A self-report measurement was used to measure KPI achievement. The performance measured used in this study was summated scale comprised of seven KPIs items as reported by sales force and their sales manager through focus group exercise. This approach is similar to Dwyer et al. (2000) who also used the items which reported by insurance agent. A five-points Likert -type scale was used to assess sales force relative performance within the banks (with $1=$ indicating for far below target, 2 = below target, 3 = meet target, 4 = exceed target and, 5 indicating far exceed target). Dwyer et al. (2000) had used this summated scale to measure respondent-generated performance among insurance agent. In the present study, salesforce KPIs achievement was generated by respondent or selfreported performance. Respondent-generated performance measures was commonly used in sales research (Johnson \& Sohi, 2014; and Shannahan et al., 2013).

\section{Results and Discussion}

Measurement and validation: The model has been assesed using SPSS Version 19. Firstly we employed factor analysis to purify measurement items for each construct. Two separate factor analyses have been conducted on independent and dependent variables respectively. The items with poor factor loading which is below 0.45 and /or with cross loading (load more than 0.35 on more than two factors) have been deleted.All items have significants loading between 0.49 to 0.79 The result ofprincipal component analysis on the independent variables revealed eight factors with eigenvalues greater than 1.0, which explained66.08 percent of total varianced. The first factor explained 37.11 percent of total variance. However, due to cross loading, only six factors were retained. After re-run the factor analyis the result of principal components analysis on dependent variable revealed that the total variance is 58.46 percent in one component. The result from factor analyis, showed that KPI achievement (DV) secured 58.4 percent of total variance from principal component analysis. This is a unidimensional construct. Table 2 shows the result regarding reliability statistics for variables used in this study. The cut of point for reliability values is set at greater than 0.7 .

Table 2: Cronbach Alpha Value for Variables

\begin{tabular}{ll}
\hline Variables & Cronbach $\boldsymbol{\alpha}$ values \\
\hline Learning & 0.826 \\
Interpersonal Skill & 0.724 \\
Presentation Skill & 0.852 \\
Articulate Visionary Leader & 0.901 \\
High Performance Culture & 0.906 \\
Teamwork & 0.878 \\
KPI Achievement & 0.849 \\
\hline
\end{tabular}

Based on the result of factors analysis, this study has six hypotheses to be tested.

H1a: There is a positive and significant relationship between sales force learning and KPI achievement. $\mathrm{H} 1 \mathrm{~b}$ : There is a positive and significant relationship between sales force interpersonal skill and KPI achievement.

H1c: There is a positive and significant relationship between sales force communication and KPI achievement.

H1d: There is a positive and significant relationship between articulate visionary leader and KPI achievement. H1e: There is a positive and significant relationship between high performance culture and KPI achievement. H1f: There is a positive and significant relationship between teamwork and KPI achievement. 
Demographic Profile: This section reports the demographic profile from the respondents. Out of 201 questionnaires collected from the respondents, 197 were useful for analysis, hence the response rate was $32.83(197 / 600)$. The breakdown of the respondents is as follows. 55 respondents from Maybank (27.9\%), 50 responses from CIMB (25.4\%), 14 from Public Bank (7.1\%), 25 from RHB Bank (12.7\%), 13 from Hong Leong Bank (6.6\%), 11 from Affin Bank (5.6\%), 28 responses from AmBank (14.2\%) and only 1 from Alliance Bank (0.5\%). 158 respondents are (80.2\%); permanent while 39 (19.8\%) are contract staff. Respondents were requested to answer several demographic questions such as their gender, age, academic qualification, race and religion. The result shows that gender distribution is slightly higher for females $(60.4 \%)$ compared to males $(39.6 \%)$. While for age distribution, majority of the respondents are in aged range between 25 and $44(92.9 \%)$, and out of this percentage, $52.8 \%$ of respondent are in age range between 25 and 29. Thus, it can be concluded that the sales force in Malaysian banks are relatively young. This was expected as the banks do have problem in retaining senior sales force and in addition senior employees are reluctant to fill up the sales position.

Most of respondents (184) or 93.4\% of sales force had diploma to master qualification. While, the remaining of respondents (13) have professional qualification and others. In terms of ethnicity and religion, the majority of the respondents are Malays (71.6\%) and Muslim (71.6\%), followed by Chinese (20.3\%) and Buddha (21.3\%), Indians (7.1\%) and Hindu (6.1\%), and others (2\%). Respondents were asked to provide information on job related such as their job tenors in same banks and sales position, performance, branch location and region. 107 respondents (54.3\%) had 1 to 5 years works experience in the same banks, whilst 38 respondents (19.3\%) already worked in the same banks between 5 to 10 years, followed by 32 respondents $(16.2 \%)$ who have more than 15 years experienced in the same banks. Only 6 respondents (3\%), who work less than 1 year in the same banks. In term of job tenors in sales position, majority of the respondents $53.3 \%$ (105 respondents) had worked in the hotel industry for more than 1 year to 5 years. 31.5\% of the respondents indicated that they had worked in the sales line between 5 years to 10 years, $5.6 \%$ had been worked between 10 years to 15 years, $7.6 \%$ had worked more than 15 years and only $2 \%$ had experienced less than 1 year. 157 sales forces respondents (79.7\%) are working in urban area and only 40 of them $(20.3 \%)$ are working in non-urban areas. In term of regional distribution, 98 sales forces (49.7\%) came from Northern, 68 sales forces (34.5\%) were from Central and the remaining 31 sales forces (15.7\%) from Southern region.

Test for Hypotheses: The hypotheses were tested using multiple regression analysis and the result is shown in Table 3. The six variables collectively explains 21 percent of the variance in KPI achievement $(R$ square $=$ 0.21 . Two of the six variables were significant namely HPC and teamwok and the remaining four were insignificant.

Table 3: Determinants of saleforce performance (KPI Achievement)

\begin{tabular}{lllll}
\hline Variables & $\begin{array}{l}\text { Regression } \\
\text { Coefficient }\end{array}$ & $\begin{array}{l}\text { Beta } \\
\text { Coefficient }\end{array}$ & $\boldsymbol{t}$ Value & $\boldsymbol{p}$ Value \\
\hline Learning & -.121 & -.125 & -1.349 & .179 \\
Interpersonal Skill & .079 & .073 & .784 & .434 \\
Communication Skill & .185 & .160 & 1.658 & .099 \\
Leader & -.036 & -.042 & -.471 & .638 \\
Hpc & .201 & .210 & 2.068 & $.040^{*}$ \\
Teamwork & .218 & .251 & 2.695 & $.008^{* *}$ \\
\hline Note ${ }^{*}<0.05^{* *}<0.01$ & & & &
\end{tabular}

\section{Analysis of Results}

Learning and KPI Achievement: The present study finds a negative and insignificant relationship between learning and KPI achievement. This means that the ability of sales force's to learn did not strongly influence KPI achievement which is supported by Kohli et al. (1998). They found that the ability of sales force to learn in two Fortune 500 companies which operate in industrial market did not give the impact to their sales performance. It is possible that the impact from ability to learn does not influence performance in short term however; it may influences sales force performance in long term. 
Hence this result does not support $\mathrm{H}_{1 \mathrm{a}}$.

Interpersonal Skill and KPI Achievement: The coefficient estimation of interpersonal is 0.07 with t-value of $0.784(\mathrm{p}>0.05)$. This result indicates that a 0.07 point increase in interpersonal skill resulted of 1 point increase in sales force KPI achievement in Malaysian retail banks. The absence of significant relationship between interpersonal skill and KPI achievement may be explained by lesser time provided by sales force for interaction successfully with others particularly with customers. However, the positive sign of the estimate indicates that the more time the sales force spends to build the relationship with their customers the higher will be the KPI achievement. Therefore, hypothesis $\mathrm{H}_{1 \mathrm{~b}}$ is rejected.

Communication and KPI Achievement: The result shows that there is a positive and not significant relationship between communication ability and KPI achievement, which indicates that higher communication could increase KPI achievement. The result is consistent with a study conducted by Verbeke, Dietz, \& Verwaal ( 2011). They found communication is not significant with sales performance. The possible reason could be that the salesforce tends to communicate with their customers relating to the banking products that they wish to sell but the products that the customers' want. Once sales have been made, the salesforce in most cases, do not follow up with their customers on the after-sales services. Hence, it effects their KPI achievement in long term. This is also due to the fact that salesforce involves more on transactional rather than relationship selling.

$\mathrm{H}_{1 \mathrm{c}}$ has not accepted.

Articulate Visionary Leader (Visionary Leader) and KPI Achievement: The coefficient estimation of visionary leader is- 0.04 with t-value of $-0.471(\mathrm{p}>0.05)$. This result indicates that an increase of 1 point in KPI achievement resulted of 0.04 point decrease in articulate visionary leadership in Malaysian retail banking. The result shows that there is a negative and not significant relationship between articulate visionary leadership and KPI achievement, which appears to suggest that articulate visionary leadership reduce encouragement among the salesforce to achieve KPIs. This finding inconsistent with Panagopoulos \& Dimitriadis (2009) in USA. The result suggest that the salesforce may be dissatisfied with the articulate visionary leader in the banks. The articulate visionary leader is fundamentally changed the values, goals, and aspirations of followers. In this case, the followers are the salesforces. They might not follow the visionary leader if the values of the leader are not consistent with the work culture (Panagopoulos \& Dimitriadis, 2009). However, according to Schwepker and Good (1999)when performance KPI target is a dominant objective, the salesforce is willing to follow the visisonary leader to make unethical decisions to make sure his/her KPI target will be achieved. It is more worsen when failing to achieve those KPI target will give the negative consequences to salesforce such as termination and reprimand (Schwepker and Good 1999). This opinion is in contrast wih the later finding of Schwepker\& Good (2010) who opined that the leader who articulates ethical principles would implement additional behaviors to avoid the potential adverse effects by the salesforce to the organization (Schwepker \& Good, 2010). Therefore, h1d rejected

High Performance Culture (HPC) and KPI Achievement: The coefficient estimation of HPC is 0.210 with tvalue of $2.068(\mathrm{p}<0.05)$. This result indicates that a 0.210 point increase in HPC, result in an increase of 1 point in KPI achievement among the sales force in Malaysian retail banks. The result shows that there is a positive and significant relationship between HPC and KPI achievement, which suggests that banks that embedded with HPC will support higher KPI achievement. This finding is consistent with Harrim (2010). One probable explanation could be that the banks with high performance culture promote high levels of engagement among their salesforce and a strong alignment of their people practices to achieve KPI targets (Nesbit, 2005). In other words, High performance culture motivates employees to improve performance by awarding them extrinsic rewards. In Malaysian banking sector, the salesforce will be rewarded generously if he/she achieve the KPI target. This practice is consistent with high performance culture organization which advocates a 'Pay for Performance Reward', where high performers are duly rewarded. Hence, $\mathrm{h}_{1 \mathrm{e}}$ accepted.

Teamwork: The result shows positive and significant relationship between teamwork and KPI achievement, which reveals that the banks which are fostering teamwork among their employees would most likely motivate their sales forces to achieve higher KPI. The result rejects null hypothesis and accept alternative hypothesis. The result in this study provides empirical evidence that of highly significant impact of teamwork 
on KPI achievement $(\beta=0.251$, t-Value $=2.695)$. This result is consistent with El-Ansary et al. $(1993)$ and Rabey (2003) who found the performance could be enhanced by the synergy of teamwork. The possible reason could be regular interactions between the employees and superior will encourage, intensify the bonds, and create an auspicious of organizational environment. In turn, it would increase commitment to the work unit's efforts. Therefore, $\mathrm{H}_{1 \mathrm{f}}$ accepted.

\section{Conclusion}

The present research has set out to investigate the relationship between the determinants namely teamwork, learning, leadership, interpersonal skills, communication and high performance culture and Key Performance Indicators (KPI). The respondents of the study are sales force in eight Malaysian commercial banking groups. Out of the six hypotheses being examined, two were supported whereby demonstrated that the significant relationship between high performance culture and teamwork, and KPI achievement. The results from this study suggest that the bank should cultivate high performance culture in the organization and nurture teamwork sprite among the employees, hence can significantly boost KPI achievement. Recognizing the importance of high performance culture, banks should give emphasis and efforts to 'engage' more employees toward this culture. The results imply that the banks should revise and improve more teamwork related activities. These include initiative for more team building and training to all employees.

Recommendation: The banks are recommended to revise sales force performance incentives individual based incentives to team-based. Formulate teamwork recognition policies also can foster the teamwork in the banks. Banks should now treat high performance culture and teamwork as critical component in sale activities of the banks. For further studies, researchers are recommended to examine the impact of micro economic variables on KPI achievement and sales performance in banking sector.

\section{References}

Albrecht, S. L. (2013). The Influence of job, team and organizational level resources on employee well being, engagement, commitment and extra-role performance. Interntaional Journal of Manpower, 33(7), 840-853.

Bell, S. J., Menguc, B. \& II, R. E. (2010). Salesperson learning, organizational learning and retail store performance. Journal of the Academic Marketing Science, 38, 187-201.

Callahan, T. (2003). How Do You Know Where You're Going if You Don't Know Where You Are? Business credit-new york then columbia md-, 105(9), 50-53.

Chen, J. C. \& Silverthorne, C. (2005). Leadership effectiveness, leadership style and employee readiness. Leadership \& Organization Development Journal, 26(4), 280-288.

Crandall, R. E. (2002). Keys to better performance measurement. Industrial Management.

Doç, Y., Akdem, B. \& Erdem, O. (2010). Characteristics of high performance. The Journal of Faculty of Economics and Administrative Sciences, 15(1), 155-175.

Downing, J. R. (2011). Linking Communication Competence with Call Centre Agent's Sales Effectiveness. Journal of Business Communication, 48(4), 409-425.

Dwyer, S., Hill, J. \& Martin, W. (2000). An empirical investigation of critical success factors in the personal

Selling process for homogenous goods. Journal of Personal Selling \& Sales Management, 20(3), 151-159.

El-Ansary, A. I., Zabriskie, N. B. \& Browning, J. M. (1993). Sales teamwork : A dominant strategy for improving saleforce. The Journal of Business \& Industrial Marketing, 8(3), 65.

Fohlke, M. C. (2006). Sales Presentation Skill and Sales Job Performance. Journal of Business and Industrial Marketing, 21(5), 311-319.

Goebel, D. J., Deeter-Schmelz, D. R. \& Kennedy, K. N. (2013). Effective Sales Management: What Do Sales People Think? Listening Skills Customer Relationship Development Open Communication Sales Rep Self-Efficacy Representative Job Performance Effective Feedback Satisfaction With Manager. Journal of Marketing Development and Competitiveness, 7(2), 11-23.

Govaerts, N., Kyndt, E., Dochy, F. \& Baert, H. (2011). Influence of learning and working climate on the retention of talented employees. Journal of Workplace Learning, 23(1), 35-55.

Grasing, R. (2003). Branch performance by the new numbers. Journal of Performance Management, 16(3), 3. 
Griffin, M. A., Patterson, Malcolm, G. \& West, M. A. (2001). Job satisfaction and teamwork: The role of supervisor support. Journal of Organizational Behaviour, 22(5), 537.

Harrim, H. M. (2010). Relationship between Learning Organization and Organizational Performance (Empirical Study of Pharmaceutical Firms in Jordan ). Jordan Journal of Business Administration, 6(3), 405-425.

Jantan, M. A. \& Honeycutt Jr, E. D. (2013). Current sales training practices in the commercial retail banking industry in Malaysia. Services Marketing Quarterly, 34(1), 1-17.

Jaramillo, F., Grisaffe, D. B., Chonko, L. B. \& Roberts, J. A. (2009). Examining the impact of servant leadership on sales force performance. Journal of Personal Selling and Sales Management, 29(3), 257-275.

Johlke, M. C. \& Duhan, D. F. (2001). Testing competing models of sales force communication. The Journal of Personall Selling \& Sales Management, 21(4), 265.

Johnson, J. S. \& Sohi, R. S. (2014). The curvilinear and conditional effects of product line breadth on salesperson performance, role stress, and job satisfaction . Journal of the Academy of Marketing Science, 42, 71-89

Karr, J. (2005). Performance measurement in banking: beyond ROE. Journal of Performance Management, 18(2), 56.

Kohli, A. K., Shervani, T. A. \& Challagalla, G. N. (1998). Learning and Performance Orientation of Salespeople : The Role of Supervisors. Journal of Marketing Research, XXXV, 263-274.

Kuvaas, B. (2007). Different relationships between perceptions of developmental performance appraisal and work performance. Personal Review, 36, 378-397.

Loveland, J. M., Lounsbury, J. W., Park, S. \& Jackson, D. W. (2015). Are salespeople born or made ? Biology , personality , and the career satisfaction of salespeople. Journal of Business \& Industrial Marketing, 30(2), 233-240

MacKenzi, S. B. \& Podsakoff, P. M. (2001). Transformational and transactional leadership and salesperson performance. Academy of Marketing Science Journal, 29(2), 115.

Mantrala, M., Sridhar, S. \& Dong, X. (. (2012). Developing India-centric B2B sales theory: an inductive approach using sales job ads. Journal of Business \& Industrial Marketing, 27(3),169 - 175.

Mualla, N. D. (2011). Assessing and measuring sales culture within commercial banks in Jordan. EuroMed Journal of Business, 6(2), 227-252.

Nesbit, P. L. (2005). HRM and the Flexible Firm : Do Firms with "High Performance" Work Cultures Utilise Peripheral Work Arrangements ? International Journal of Employment Studies, 13(2), 1-18.

Nik Kamariah, N. M. (1995). Determinants of sales performance in insurance industry: A cross cultural comparison between the United kingdom and Malaysia. Unpublished doctoral thesis. University of Aston. UK.

Panagopoulos, N. \& Dimitriadis, S. (2009). Transformational leadership as a mediator of the relationship between behavior-based control and salespeople's key outcomes An initial investigation. European Journal of Marketing, 43(7/8), 1008-1031.

Piercy, N. F., W.Cravens, D., Nikala, L. \& Vorhies, D. W. (2006). Driving Organizational Citizenship Behaviors and Salesperson In-Role Behaviour Performance: The Role of Management Control and Perceived Organizational Support. Journal of the Academy of Marketing Science, 34(2).

Rabey, G. (2003). The paradox of teamwork. Industrial and Commercial Training, 35(4), 158 -162.

Robson, I. (2005). Implementing a performance measurement system capable of creating a culture of high performance. International Journal of Productivity and Performance Management, 54(2), 137-145

Rodriguez, D., Patel, R., Bright, A., Gregory, D. \& Gowing, M. K. (2002). Developing competency models to promote integrated human resource practices. Human Resource Management, 41(3), 309-324

Shannahan, K. L. J., Bush, A. J. \& Shannahan, R. J. (2013). Are your salespeople coachable? How salesperson coachability, trait competitiveness, and transformational leadership enhance sales performance. Journal of The Academy of Marketing Science, 41, 40-54.

Scudder, J. N. \& Guinan, P. J. (1989). Communication competencies as discriminators of superiors' ratings of employee performance. Journal of Business Communication, 26(3), 217-229.

Shannahan, K. L., Bush, A. J. \& Shannahan, R. J. (2013). Are your salespeople coachable? How salesperson coachability, trait competitiveness, and transformational leadership enhance sales performance. Journal of the Academy Marketing Science, 41, 40-54

Spencer, L. M. \& Spencer, S. M. (1993). Competence at work: Models for superior performance. New York: John Wiley \& Sons, Inc. 
Schwepker, Jr C. H. \& Good, David, J. (1999) "The impact of sales quotas on moral judgment in the financial services industry. Journal of Services Marketing, 13(1), 38-58.

Schwepker, C. H. \& Good, D. J. (2010a). Transformational Leadership and its Impact on Sales Force Moral Judgment. Journal of Personal Selling and Sales Management, 30(4), 299-318.

Titko, J. \& Lace, N. (2010). Performance Measures for a Business Unit in Latvian Retail Banking. In 6-th International Scientific Conference Business and Management 2010 (pp. 13-14).

Verbeke, W., Dietz, B. \& Verwaal, E. (2011). Drivers of Sales performance: A contemporary meta analysis: Have salespeople becomes knowledge workers. Journal of Academy Marketing Science, 39, 407-428.

Williams, M. R. \& Attaway, J. S. (1996). Exploring salespersons' customer orientation as a mediator of organizational culture's influence on buyer-seller relationship. Journal of Personal Selling and Sales Management, XVI(4), 33-52.

$\mathrm{Wu}, \mathrm{H}$. Y. (2012). Constructing a strategy map for banking institutions with key performance indicators of the balanced scorecard. Evaluation and Program Planning, 35, 303-320.

Wua, H. Y., Tzeng, G. H. \& Chen, Y. H. (2009). A fuzzy MCDM approach for evaluating banking performance based on Balanced Scorecard. Expert Systems with Applications, 36(6), 10135-10147.

Yukl, G. (2012). Effective leadership behaviour: What we know and what questions need more attention. Academy of Management Perspectives, 2, 66-85.

Zakaria, Z., Yaacob, M., 'Aini, Yaacob, Z., Noordin, N., Sawal, M. Z. H. M. \& Zakaria, Z. (2011). Key Performance Indicators (KPIs) in the Public Sector: A Study in Malaysia.Asian Social Science, 7(7), 102-108. 